\title{
Catastrophic drug coverage: utilization insights from the Ontario Trillium Drug Program
}

\author{
Mina Tadrous PharmD PhD, Simon Greaves MSc, Diana Martins MSc, \\ Muhammad M. Mamdani PharmD MPH, David N. Juurlink MD PhD, Tara Gomes MHSc PhD
}

Abstract

Background: Catastrophic drug coverage programs help those with high drug-costs to reduce the burden of out-of-pocket expenses. We set out to measure changes in utilization, spending and demographic profiles of people accessing Ontario's catastrophic drug program, the Trillium Drug Program.

Methods: We conducted a cross-sectional time-series analysis examining quarterly utilization and spending trends among medications reimbursed by the Trillium Drug Program in Ontario, Canada from Jan. 1, 2000, to Dec. 31, 2016. In each of 2000, 2005, 2010 and 2015, we described the population of beneficiaries, including demographic information, health care utilization and medication utilization.

Results: Over our study period, use of the Trillium Drug Program increased threefold from 3.6 beneficiaries per 1000 to 10.9 beneficiaries per 1000 Ontarians, and total government spending on the program increased by over $700 \%$, reaching $\$ 487$ million in 2016 . Between 2000 and 2015, there was an increase in the number of beneficiaries who were under the age of 35 years (19.6\% to $25.3 \%$; $p<0.0001$ ), did not have a hospital admission (68.3\% to $80.5 \% ; p<0.0001$ ) and had medium to high deductibles $(2.3 \%$ to $8.0 \% ; p<$ $0.0001)$. Further, there was a large increase in the percentage of users with drug claims greater than $\$ 1000(3.4 \%$ to $10.4 \% ; p<$ $0.0001)$ and those dispensed a high-cost biologic drug ( $1.6 \%$ to $5.5 \% ; p<0.0001)$.

Interpretation: Increasing use of Ontario's catastrophic drug program highlights the growing burden of high drug prices for Canadians. With a growing number of expensive drugs being approved in Canada, we anticipate that spending and use of the catastrophic drug program will continue to expand.

$\mathrm{P}$ ublic drug plans have long struggled with rising drug costs. ${ }^{1}$ This burden may be potentiated by the increasing prevalence of precarious work and stagnant growth in household income, which has allowed the pressure of rising drug costs to increase on Canadian households. ${ }^{2,3}$ Increasing drug prices have forced more private insurers and employers to enact stricter drug formularies and introduce higher deductibles as they look for ways to control spending, possibly placing even greater pressure on public drug plans. ${ }^{4,5}$ Public drug programs in most regions in Canada are reasonably comprehensive and have implemented programs to help those with high out-of-pocket drugs costs compared with household income, which are often termed catastrophic drug coverage programs. In Ontario, this program is called the Trillium Drug Program (TDP). ${ }^{6}$ Eligibility for catastrophic drug coverage programs varies across the country but all those not enrolled in a public drug program are eligible. In Ontario, three-quarters of residents are not covered by the public drug programs and are either privately insured (53\%) or uninsured (21\%); they are eligible for the TDP if they spend more than $4 \%$ of their household income on prescription drugs.?

With rising drug prices and a growing number of new therapies being approved, questions around the effects of increasing drug costs on Canadians are being raised. ${ }^{1}$ Additionally, overburdened by the rising price of expensive drugs, private payers may be leveraging the TDP as a means to reduce costs. Recent attention on the need for a national pharmacare strategy has largely focused on the coverage of essential medications, which does not address the rising cost of expensive drugs and the burden it places on Canadians. ${ }^{8-10}$ We set out to measure the changing patterns in drug utilization, government spending and characteristics of people eligible for the Ontario TDP to better understand the burden of rising drug costs and use of catastrophic drug coverage in Ontario.

\section{Methods}

We conducted a cross-sectional time series analysis examining the quarterly trends in drug utilization and associated govern-

Competing interests: Muhammad Mamdani has received honoraria from Novo Nordisk, Allergan and Celgene. No other competing interests were declared.

This article has been peer reviewed.

Correspondence to: Mina Tadrous, tadrousm@smh.ca

CMAJ Open 2018. DOI:10.9778/cmajo.20170132 
ment spending through the TDP in Ontario, Canada, between Jan. 1, 2000, and Dec. 31, 2016. In a secondary analysis, we described the changing characteristics of beneficiaries among annual cohorts of TDP beneficiaries at 4 time points over the course of our study period (2000, 2005, 2010 and 2015).

\section{Data sources}

We used the Ontario Drug Benefit (ODB) claims database to identify all drugs dispensed to individuals reimbursed through the TDP in Ontario. We identified hospital admissions and emergency department (ED) visits using the Canadian Institute for Health Information's Discharge Abstract Database and National Ambulatory Care Reporting System, respectively. We used the Ontario Health Insurance Plan (OHIP) Claims History Database to identify physician visits. Beneficiary demographics, place of residence and vital status information were obtained from the OHIP Registered Persons Database. These databases, which are securely linked using unique, encoded identifiers and analyzed at the Institute for Clinical Evaluative Sciences (ICES), are routinely used to examine drug safety and effectiveness. ${ }^{11-13}$

\section{Analysis}

In our primary analysis, we identified all individuals under the age of 65 years who were dispensed a prescription that was reimbursed by the TDP. Those over 65 years of age were excluded because they have universal access to public drug coverage in Ontario. We reported the total number and population-adjusted rate of active beneficiaries, the total spending by the Ontario public drug programs (OPDP) and the proportion of beneficiaries with a single claim over $\$ 1000$ in each quarter over the study period. Rates were reported per 1000 eligible population, defined as the Ontario population under the age of 65 years who were not beneficiaries of other ODB programs. We also reported annual spending in present value using a discount rate of $1.5 \% .^{14}$

In our secondary analysis, we created annual cohorts of beneficiaries under the age of 65 years defined above at 4 time points over our study period (2000, 2005, 2010 and 2015). Among these cohorts, we defined patient characteristics at the time of the first prescription reimbursed by the TDP. We reported demographic information (age, sex and socioeconomic status), deductible status (i.e., whether the beneficiary surpassed their predefined deductible during the year), quarterly deductibles (low [< \$350], medium [\$351-\$499] and high [> \$500]), Charlson Comorbidity Index scores, ${ }^{15}$ number of medications used during the year, use of expensive medications (1 or more claims costing more than $\$ 1000$ ) and use of a high-cost biologic drug. In Ontario, the deductible is calculated on the basis of household income and the number of residents in the household. Beneficiaries' deductibles are equal to approximately $4 \%$ of annual household income, adjusted for the number of dependents, which is then divided quarterly. High-cost biologic drugs were defined as any biologic agent as defined by Health Canada excluding insulins and low-molecular-weight heparins. We used the Spearman rank correlation for continuous characteristics and the Cochrane-Armitage test for categorical characteristics to test for trends across years. Finally, we reported the top
10 most commonly reimbursed medications by total number of users and the top 10 most costly reimbursed medications based on total annual spending in each annual cohort.

\section{Ethics approval}

This project was approved by the Research Ethics Board of Sunnybrook Health Sciences Centre, Toronto.

\section{Results}

Between Jan. 1, 2000, and Dec. 31, 2016, the rate of beneficiaries in the TDP increased $202 \%$ from 3.6 beneficiaries per 1000 eligible population ( $n=37436$ ) in Q1-2000 to 10.9 beneficiaries per 1000 eligible population $(n=128166)$ in Q4-2016 (Figure 1). The rate of growth in beneficiaries was most pronounced from 2000 to 2011, with an average annual growth of $11.3 \%$ and a subsequent plateau in the rate of users between 2011 and 2016. Total spending by the OPDP on the TDP increased by $735 \%$ over the same period, from $\$ 15.25$ million in Q1-2000 to \$127.42 million in Q4-2016. In 2016, the total annual expenditure on the TDP reached $\$ 487$ million, an increase of $840 \%$ from $\$ 51$ million (present-day value) in 2000 (Appendix 1, Supplemental Figure 1, available at www. cmajopen.ca/content/6/1/E132/supp1/DC1). Unlike the number of users, spending by the OPDP did not plateau in 2011, but rather continued to grow throughout the study period. The proportion of beneficiaries receiving high-cost drugs (i.e., $>\$ 1000$ claim) similarly increased by $344 \%$, from $2.5 \%$ of beneficiaries in Q1-2000 to 11.1\% in Q4-2016 (Figure 2).

We observed several important changes in the characteristics of TDP beneficiaries between 2000 and 2015 (Table 1). First, the proportion of beneficiaries who received only 1 drug over the course of the year nearly doubled, growing from $11.2 \%$ of beneficiaries in 2000 to $18.2 \%$ in $2015(p<0.0001)$. Inversely, the proportion of users receiving more than $1 \mathrm{drug}$ decreased from $88.8 \%$ of beneficiaries in 2000 to $81.2 \%$ in 2015. Despite this, the majority of beneficiaries surpassing their deductible remained stable over time, ranging from $92.4 \%$ to $95.0 \%$ annually. The demographic profile of beneficiaries also changed, with the program being accessed more frequently by younger beneficiaries in $2015(13.5 \%$ v. $17.6 \%$ were aged $<24 \mathrm{yr}$ in 2000 and 2015, respectively, $p<0.0001$ ). Evidence of an increase in the use of the TDP by individuals with middle and high deductibles was also observed $(p<0.0001)$. Specifically, there was an increase in the number and proportion of beneficiaries with middle (\$351-\$499) and high $(>\$ 500)$ deductibles (1.4\% to $3.6 \%$ and $0.9 \%$ to $4.4 \%$, respectively $(p<$ $0.0001)$ ). However, despite this, it continues to be the case that the the program is predominantly used by those in groups with lower deductibles (92.0\% in 2015). Finally, TDP beneficiaries had fewer hospital admissions, with the proportion of those having no inpatient hospital admissions growing from $68.3 \%$ to $80.5 \%$ between 2000 and $2015(p<0.0001)$.

There have also been considerable changes in the patterns of medication use among TDP beneficiaries. We found a large increase in the percentage of users with drug claims greater than $\$ 1000$ (3.4\% to $10.4 \%$; $p<0.0001$ ) or for a high- 


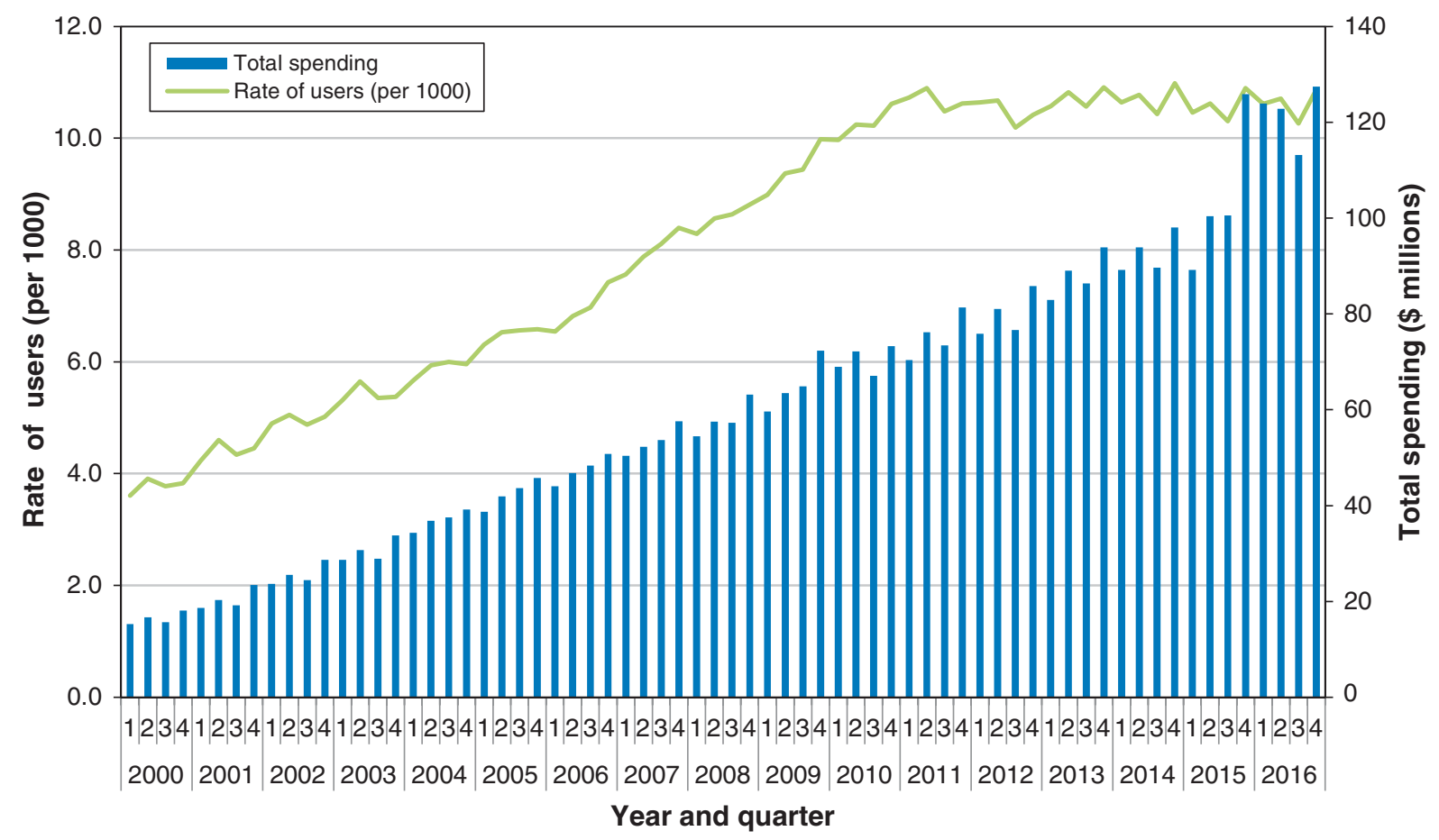

Figure 1: Rate of Ontario Trillium Drug Program beneficiaries per 1000 and total program spending from 2000 to 2016, by year and quarter.

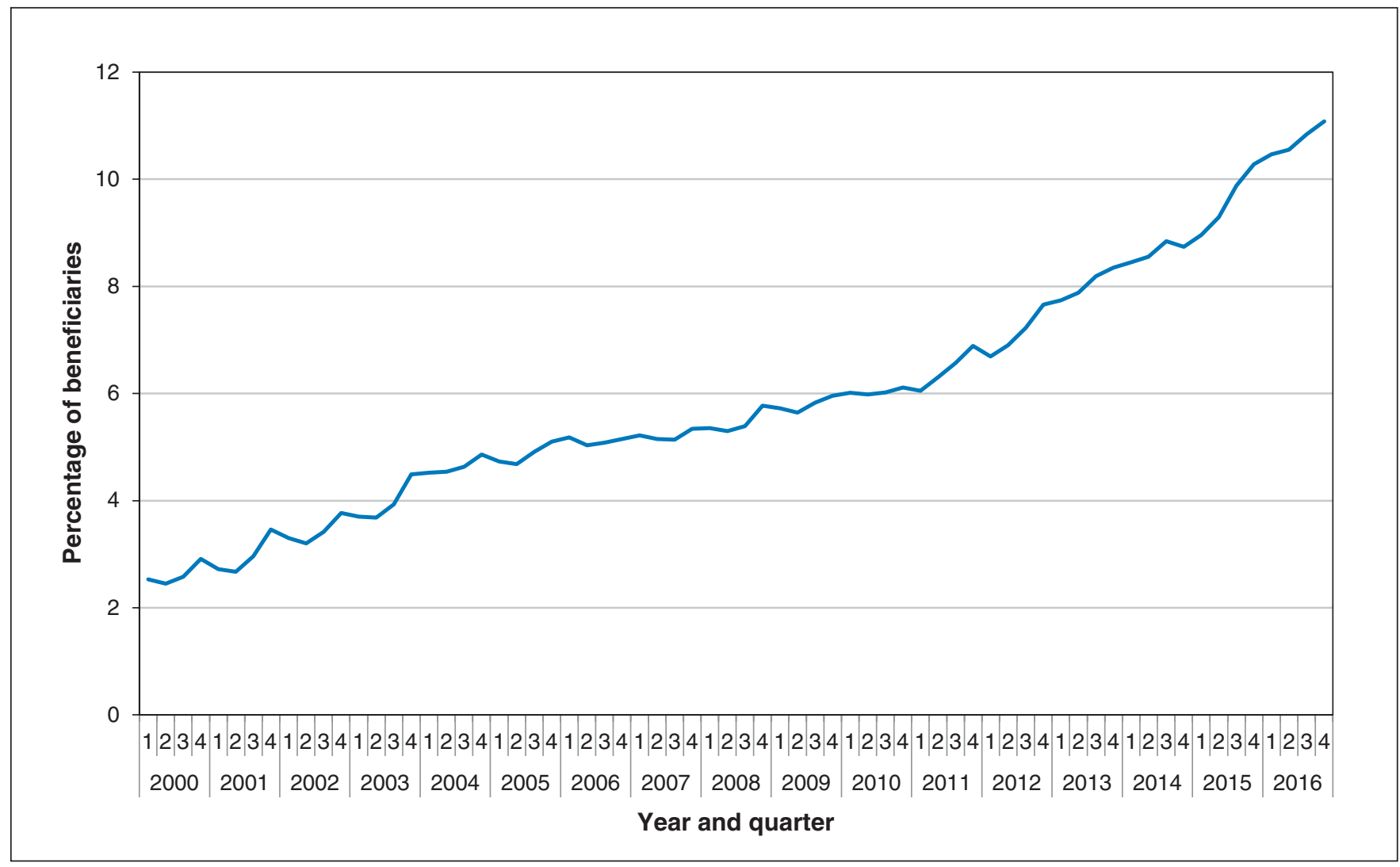

Figure 2: Percentage of Ontario Trillium beneficiaries from 2000 to 2016 with any single claim over $\$ 1000$, by year and quarter. 


\begin{tabular}{|c|c|c|c|c|}
\hline \multirow[b]{2}{*}{ Characteristic } & \multicolumn{4}{|c|}{ Year } \\
\hline & 2000 & 2005 & 2010 & 2015 \\
\hline No. of TDP recipients & 55571 & 95296 & 162301 & 176299 \\
\hline $\begin{array}{l}\text { No. of TDP recipients surpassing deductible, } \\
n(\%)\end{array}$ & $51320(92.4)$ & $90564(95.0)$ & $150229(92.6)$ & $163140(92.5)$ \\
\hline Total TDP spending, \$ & 65717445 & 170049300 & 281546814 & 416019977 \\
\hline $\begin{array}{l}\text { Average annual cost per recipient } \\
\text { surpassing deductible, } \$\end{array}$ & 1281 & 1878 & 1874 & 2550 \\
\hline Median age, yr (Q1-Q3) & $53(43-63)$ & $53(43-63)$ & $52(41-63)$ & $52(40-64)$ \\
\hline \multicolumn{5}{|l|}{ Age category, yr, $n(\%)$} \\
\hline $0-24$ & $7507(13.5)$ & $14099(14.8)$ & $27020(16.6)$ & $30943(17.6)$ \\
\hline $25-34$ & $3387(6.1)$ & $5554(5.8)$ & $10633(6.6)$ & $13504(7.7)$ \\
\hline $35-49$ & $11849(21.3)$ & $20286(21.3)$ & 34194 (21.1) & 35024 (19.9) \\
\hline $50-64$ & $32828(59.1)$ & $55357(58.1)$ & $90454(55.7)$ & 96828 (54.9) \\
\hline \multicolumn{5}{|l|}{ No. of drugs, $n(\%)$} \\
\hline 1 & $5,773(11.2)$ & $10942(12.1)$ & $21460(14.3)$ & $29662(18.2)$ \\
\hline 2 & $5,765(11.2)$ & $10373(11.5)$ & $18115(12.1)$ & $19731(12.1)$ \\
\hline$\geq 3$ & $39782(77.5)$ & $69249(76.5)$ & $110654(73.7)$ & $113747(69.7)$ \\
\hline Sex, male, $n(\%)$ & $22767(41.0)$ & 39801 (41.8) & $69976(43.1)$ & 77551 (44.0) \\
\hline \multicolumn{5}{|l|}{ Income quintile, $n(\%)$} \\
\hline 1 (lowest) & $14838(26.7)$ & 26628 (27.9) & $44417(27.4)$ & $45789(26.0)$ \\
\hline 2 & $13465(24.2)$ & 22366 (23.5) & $37289(23.0)$ & $40225(22.8)$ \\
\hline 3 & $10856(19.5)$ & $18212(19.1)$ & 32319 (19.9) & $35898(20.4)$ \\
\hline 4 & $9183(16.5)$ & $15751(16.5)$ & $27847(17.2)$ & $31493(17.9)$ \\
\hline 5 (highest) & $7127(12.8)$ & $12123(12.7)$ & $20082(12.4)$ & $22492(12.8)$ \\
\hline \multicolumn{5}{|l|}{ Charlson Comorbidity Index score, $n(\%)$} \\
\hline No hospital admission & $35058(68.3)$ & $66600(73.5)$ & $117491(78.2)$ & $131290(80.5)$ \\
\hline 0 & $7869(15.3)$ & $12514(13.8)$ & $16238(10.8)$ & $15572(9.6)$ \\
\hline 1 & $3873(7.6)$ & $5242(5.8)$ & $6886(4.6)$ & $6523(4.0)$ \\
\hline$\geq 2$ & $4520(8.8)$ & $6208(6.9)$ & $9614(6.4)$ & $9755(6.0)$ \\
\hline Single claims $>\$ 1000$ & $1757(3.4)$ & $5170(5.7)$ & $10021(6.7)$ & $17015(10.4)$ \\
\hline Any biologic use & $4119(8.0)$ & $8397(9.3)$ & $15985(10.6)$ & $21779(13.4)$ \\
\hline High-cost biologics & $807(1.6)$ & $2711(3.0)$ & $5061(3.4)$ & $8952(5.5)$ \\
\hline \multicolumn{5}{|l|}{ Deductible, $n(\%)$} \\
\hline Low $(<\$ 350)$ & $50180(97.8)$ & 86055 (95.0) & 139489 (92.9) & $150092(92.0)$ \\
\hline Med (\$351-499) & $699(1.4)$ & $2468(2.7)$ & 5595 (3.7) & $5895(3.6)$ \\
\hline High (> \$500) & $441(0.9)$ & 2041 (2.3) & $5145(3.4)$ & $7153(4.4)$ \\
\hline Median deductible, \$ & 42 & 65 & 69 & 58 \\
\hline
\end{tabular}

cost biologic $(1.6 \%$ to $5.5 \% ; p<0.0001)$ between 2000 and 2015 (Table 1). The most frequently reimbursed drugs in the TDP remained relatively consistent over time and were com- monly prescribed medications (e.g., acetaminophen/codeine, amoxicillin and atorvastatin; Table 2). In contrast, the medications with the highest total spending changed over time, 
shifting from chronic oral medications (the highest cost drug in 2000 was atorvastatin $[\$ 2.6 \mathrm{M}]$ ) to newer biologic agents (the highest cost drug in 2015 was infliximab [\$55.4M]). HIV and hepatitis $\mathrm{C}$ treatments remained some of the highest costing medications for the program throughout our study period.

\section{Interpretation}

We found a significant increase in the use and spending of catastrophic drug coverage through the TDP over the last 15 years in Ontario. This large increase in spending appears to be correlated with an increase in the use of high-cost medications, including biologic treatments. We also observed a shift in the characteristics of beneficiaries, with a shift toward younger, healthier adults, and more individuals with middle and high deductibles accessing the program.

A number of factors may have contributed to this rapid growth in the use of the TDP. The preceding decade experienced a large number of small-molecule blockbuster drugs with high prevalence of use (e.g., atorvastatin and ramipril). Increased prescribing along with developing clinical guidelines may have increased out-of-pocket drug expenditures for a large proportion of the population, increasing the need for a catastrophic drug program. While the number of beneficiaries continued to grow after 2010, the rate of growth slowed, probably because of a number of intervening policy and industry changes to the pricing of common medications. First, the Ontario government introduced reductions to the price of generic drugs in 2010. Consequently, the cost of generics went from as high as $90 \%$ of the brand-name originator cost down to $25 \%$ and as low as $15 \%$ after a series of policy changes. ${ }^{16}$ This change in generic drug prices may have reduced the demand for catastrophic drug coverage by Ontarians taking more common medications and also reduced the likelihood of crossing the $4 \%$ deductible threshold. Second, during this time period a number of products lost patent exclusivity, further reducing drug price expenditures on high-prevalence treatments. While additional analysis is required to confirm these possibilities, they each suggest that in general drug products with higher prevalence may contribute to the number of residents seeking assistance for their drug expenditures but this does not explain the continuing increase in spending.

Despite a levelling off of the growth rate of TDP beneficiaries, drug expenditures have continued to rise. The spending for the TDP has grown much faster than the national rate of public drug spending, which was reported by the Canadian Institute for Health Information to grow at an average rate of $10.6 \%$ per year between 1985 and 2005 and at a rate of $7.6 \%$ between 2005 and $2010 .{ }^{17}$ In contrast, TDP spending grew an average of $21 \%$ between 2000 and 2005 and $11 \%$ between 2005 and 2010. Since 2010, the average rate of growth for the TDP has been $10 \%$, much higher than the national rate of growth of $1.6 \%$. This sharp increase may be correlated with an increase in spending on high-cost medications and biologic treatments rather than medications for common chronic conditions. The rising price of new drugs outpaced the consumer price index almost every year from 1992 to 2014. Moreover, the number of drugs with higher price tags has also increased over this time. It is no longer unusual for newly approved treatments to cost more than $\$ 1000$ monthly. Even more apparent is the number of newly approved drugs costing over $\$ 10000$ annually, which has increased from 20 drugs in 2005 to 124 in $2015 . .^{18}$ The impact of these trends on medication affordability is supported by our findings that the proportion of TDP beneficiaries taking only $1 \mathrm{drug}$, those with a single claim above $\$ 1000$ and uptake of high-cost biologics increased over the study period. Furthermore, access increased among younger, wealthier patients and patients with a low comorbidity index score. Overall, the patterns observed in this study suggest that the increasing availability of expensive medications may be placing a great economic burden on Ontarians.

Our analysis revealed that a growing number of younger beneficiaries (aged 0-24 yr) and new entrants to the workforce (aged 25-34 yr) need drug coverage assistance. Current labour force trends, especially among younger adults, are leading to a larger prevalence of individuals with no private health insurance (both for themselves and their dependents) in the province, a trend that may be exacerbated by stagnant growth in household income and a rising cost of living. ${ }^{19}$ Recent evidence suggests that over one-third of Ontarians who are employed do not have private insurance, with higher rates among lower earners and part-time workers. ${ }^{2}$ Considering that the median family income after tax in Canada is $\$ 75700,{ }^{19}$ the highest deductible for a 1 -person home would be $\$ 3028$ per year, a value easily surpassed with a single prescription for many biologics. Current discussions around comprehensive pharmacare policies should account for this population, which faces a high financial burden for important treatment modalities.

The results of our study are important for informing the development of provincial and national pharmacare strategies. In particular, our study highlights the importance of addressing the needs of those receiving high-cost medications and the impact of the quickly rising costs of new medications. Recent attention on pharmacare strategies has largely focused on the need for coverage of essential medications and has ignored the rising cost of new and expensive medications. ${ }^{8,20}$ Importantly, we found that an increasing proportion of beneficiaries are in the groups with middle and high deductibles, signalling an increasing economic burden of rising drug costs. Our results may be influenced by current private payer trends as employers and private insurers, overburdened by the price of expensive drugs, may be leveraging the TDP as a means of saving costs. ${ }^{21}$ This strategy, termed coordination of benefits, has emerged as an increasingly popular strategy to mitigate the growing risk of high-cost medications. The extent to which this is occurring is unknown. Second, in light of the introduction of the OHIP+ program in Ontario on Jan. 1, 2018, which covers all drugs for residents under 25 years of age, our study highlights the growing utilization of expensive drugs in younger populations. Expansion of pharmacare to younger populations across Canada should account for this rise in spending. Lastly, spending of the TDP grew at a much faster rate than overall drug spending. Including this population in a pharmacare strategy would allow for negotiations on a pan-Canadian level, which in turn 
Table 2: Top 10 drugs by use and cost in calendar years 2000, 2005, 2010 and 2015

\begin{tabular}{|c|c|c|c|c|}
\hline \multirow[b]{2}{*}{ Rank } & \multicolumn{4}{|c|}{ Year } \\
\hline & 2000 & 2005 & 2010 & 2015 \\
\hline \multicolumn{5}{|c|}{ Top drugs by frequency of use, $n^{*}(\%)$} \\
\hline 1 & $\begin{array}{l}\text { APAP, caffeine and codeine } \\
9119(16.4)\end{array}$ & $\begin{array}{l}\text { Atorvastatin } \\
18014(18.9)\end{array}$ & $\begin{array}{c}\text { Metformin } \\
26486(16.3)\end{array}$ & $\begin{array}{l}\text { Rosuvastatin } \\
27452(15.6)\end{array}$ \\
\hline 2 & $\begin{array}{l}\text { Amoxicillin } \\
7367 \text { (13.3) }\end{array}$ & $\begin{array}{l}\text { APAP, caffeine and codeine } \\
14069(14.8)\end{array}$ & $\begin{array}{l}\text { Atorvastatin } \\
24940(15.4)\end{array}$ & $\begin{array}{c}\text { Amoxicillin } \\
24686(14.0)\end{array}$ \\
\hline 3 & $\begin{array}{l}\text { Estrogen } \\
7097(12.8)\end{array}$ & $\begin{array}{l}\text { Amoxicillin } \\
13437(14.1)\end{array}$ & $\begin{array}{c}\text { Amoxicillin } \\
23214(14.3)\end{array}$ & $\begin{array}{c}\text { Metformin } \\
23990(13.6)\end{array}$ \\
\hline 4 & $\begin{array}{l}\text { Atorvastatin } \\
6293(11.3)\end{array}$ & $\begin{array}{c}\text { Metformin } \\
13321(14.0)\end{array}$ & $\begin{array}{l}\text { Rosuvastatin } \\
22419(13.8)\end{array}$ & $\begin{array}{l}\text { Atorvastatin } \\
19859(11.3)\end{array}$ \\
\hline 5 & $\begin{array}{l}\text { Ranitidine } \\
6260(11.3)\end{array}$ & $\begin{array}{c}\text { Ramipril } \\
13207 \text { (13.9) }\end{array}$ & $\begin{array}{c}\text { APAP, caffeine and codeine } \\
18459(11.4)\end{array}$ & $\begin{array}{c}\text { Albuterol } \\
19571(11.1)\end{array}$ \\
\hline 6 & $\begin{array}{c}\text { Albuterol } \\
5575(10.0)\end{array}$ & $\begin{array}{c}\text { Albuterol } \\
10226(10.7)\end{array}$ & $\begin{array}{c}\text { Ramipril } \\
17330(10.7)\end{array}$ & $\begin{array}{l}\text { Levothyroxine } \\
16865 \text { (9.6) }\end{array}$ \\
\hline 7 & $\begin{array}{l}\text { Lorazepam } \\
5427(9.8)\end{array}$ & $\begin{array}{l}\text { Hydrochlorothiazide } \\
10023(10.5)\end{array}$ & $\begin{array}{c}\text { Albuterol } \\
17016(10.5)\end{array}$ & $\begin{array}{c}\text { APAP, caffeine and codeine } \\
14435(8.2)\end{array}$ \\
\hline 8 & $\begin{array}{l}\text { Levothyroxine } \\
5283 ;(9.5)\end{array}$ & $\begin{array}{l}\text { Levothyroxine } \\
9141(9.6)\end{array}$ & $\begin{array}{l}\text { Levothyroxine } \\
15297(9.4)\end{array}$ & $\begin{array}{l}\text { Amlodipine } \\
14258(8.1)\end{array}$ \\
\hline 9 & $\begin{array}{l}\text { Metformin } \\
4862(8.7)\end{array}$ & $\begin{array}{l}\text { Lorazepam } \\
8183(8.6)\end{array}$ & $\begin{array}{l}\text { Rabeprazole } \\
13904(8.6)\end{array}$ & $\begin{array}{l}\text { Pantoprazole } \\
13868 \text { (7.9) }\end{array}$ \\
\hline 10 & $\begin{array}{l}\text { Glyburide } \\
4292(7.7)\end{array}$ & $\begin{array}{l}\text { Amlodipine } \\
7702(8.1)\end{array}$ & $\begin{array}{l}\text { Amlodipine } \\
13418(8.3)\end{array}$ & $\begin{array}{c}\text { Ramipril } \\
12380(7.0)\end{array}$ \\
\hline \multicolumn{5}{|c|}{ Top drugs by total spending, $\$+(\%)$} \\
\hline 1 & $\begin{array}{c}\text { Atorvastatin } \\
2600000(4.0)\end{array}$ & $\begin{array}{c}\text { Infliximab } \\
10450000(6.1)\end{array}$ & $\begin{array}{c}\text { Infliximab } \\
31830000(11.3)\end{array}$ & $\begin{array}{c}\text { Infliximab } \\
55370000(13.3)\end{array}$ \\
\hline 2 & $\begin{array}{l}\text { Interferon } \alpha 2 b \text { and ribavirin } \\
22240000 \text { (3.4) }\end{array}$ & $\begin{array}{c}\text { Atorvastatin } \\
7900000(4.6)\end{array}$ & $\begin{array}{c}\text { Etanercept } \\
11070000(3.9)\end{array}$ & $\begin{array}{l}\text { Ledipasvir and sofosbuvir } \\
\qquad 24620000(5.9)\end{array}$ \\
\hline 3 & $\begin{array}{c}\text { Interferon } \beta \\
2080000(3.2)\end{array}$ & $\begin{array}{l}\text { Interferon } \beta 1 a \\
7000000(4.1)\end{array}$ & $\begin{array}{l}\text { Interferon } \beta 1 a \\
9339000(3.3)\end{array}$ & $\begin{array}{c}\text { Adalimumab } \\
23520000(5.7)\end{array}$ \\
\hline 4 & $\begin{array}{l}\text { Interferon } \beta 1 a \\
2050000(3.1)\end{array}$ & $\begin{array}{c}\text { Imatinib } \\
4980000(2.9)\end{array}$ & $\begin{array}{l}\text { Oxycodone } \\
8180000(2.9)\end{array}$ & $\begin{array}{c}\text { Etanercept } \\
14340000(3.4)\end{array}$ \\
\hline 5 & $\begin{array}{l}\text { Omeprazole } \\
1970000(3.0)\end{array}$ & $\begin{array}{c}\text { Etanercept } \\
4700000(2.8)\end{array}$ & $\begin{array}{l}\text { Adalimumab } \\
8100000(2.9)\end{array}$ & $\begin{array}{c}\text { Tenofovir } \\
10900000(2.6)\end{array}$ \\
\hline 6 & $\begin{array}{c}\text { Olanzapine } \\
1710000(2.6)\end{array}$ & $\begin{array}{c}\text { Olanzapine } \\
3920000(2.3)\end{array}$ & $\begin{array}{c}\text { Imatinib } \\
\$ 6900000(2.5)\end{array}$ & $\begin{array}{c}\text { Eculizumab } \\
10040000(2.4)\end{array}$ \\
\hline 7 & $\begin{array}{l}\text { Lamivudine } \\
1700000(2.6)\end{array}$ & $\begin{array}{l}\text { Lamivudine and zidovudine } \\
\qquad 3280000(1.9)\end{array}$ & $\begin{array}{l}\text { Rosuvastatin } \\
6500000(2.3)\end{array}$ & $\begin{array}{c}\text { Interferon } \beta 1 \mathrm{a} \\
73760000(1.8)\end{array}$ \\
\hline 8 & $\begin{array}{c}\text { Nelfinavir } \\
1420000(2.2)\end{array}$ & $\begin{array}{c}\text { Oxycodone } \\
3250000(1.9)\end{array}$ & $\begin{array}{c}\text { Atorvastatin } \\
6420000(2.3)\end{array}$ & $\begin{array}{c}\text { Efavirenz, emtricitabine and } \\
\text { tenofovir } \\
71010000(1.7)\end{array}$ \\
\hline 9 & $\begin{array}{c}\text { Stavudine } \\
1400000(2.1)\end{array}$ & $\begin{array}{c}\text { Ramipril } \\
3060000 \text { (1.8) }\end{array}$ & $\begin{array}{c}\text { Efavirenz, emtricitabine and } \\
\text { tenofovir } \\
6350000(2.3)\end{array}$ & $\begin{array}{l}\text { Sofosbuvir } \\
6740000(1.6)\end{array}$ \\
\hline 10 & $\begin{array}{l}\text { Lamivudine and zidovudine } \\
\qquad 1360000(2.1)\end{array}$ & $\begin{array}{c}\text { Omeprazole } \\
3040000(1.8)\end{array}$ & $\begin{array}{l}\text { Abacavir and lamivudine } \\
5000000(1.8)\end{array}$ & $\begin{array}{l}\text { Lenalidomide } \\
6720000(1.6)\end{array}$ \\
\hline $\begin{array}{l}\text { Note: } \\
{ }^{*} \text { No. } 0 \\
\text { †Dolla }\end{array}$ & $\begin{array}{l}\text { aminophen. } \\
\text { orted to the nearest } \$ 10000 \text {. }\end{array}$ & & & \\
\hline
\end{tabular}

could allow for greater cost savings. Negotiations by public payers, termed price listing agreements, for new agents have proven to be an opportunity for cost savings for payers. ${ }^{22}$ In fact, a recent report by the Auditor General cited a cost savings of $\$ 1.1$ billion in fiscal year 2016-17 to the OPDP directly from rebates by manufacturers. ${ }^{23}$ Policies aiming to control the 
costs of newer agents entering the Canadian market would greatly curb the burden of rising costs on Canadians. National strategies must address the growing financial burden of drug costs for the entire population.

\section{Limitations}

Some limitations of our study warrant emphasis. We did not have access to the actual household income of individuals so we must infer that the rise in deductibles, which are determined on the basis of household income, is correlated with increases in household income. However, because there were no policy changes on deductible thresholds over our study period, we do not believe that this affected our findings. Second, we did not have any information on the private insurance status for beneficiaries. Therefore, we were unable to determine whether the growth in use of the TDP was being influenced by private insurers reducing coverage for expensive treatments or by more individuals with no insurance requiring the program. Future research should explore the current dynamic between private and public payers in light of the rising drug costs. Third, we did not account for the effectiveness or cost-effectiveness of the TDP or treatments; this is an important area of future work. Lastly, this study used only Ontario data and thus may not be generalizable to the rest of Canada. Importantly, although this study was limited to Ontario, much of the information we have on drug pricing and labour trends is national, and we can therefore anticipate that similar trends hold true across Canada. Comparative studies of the use of catastrophic drug programs nationally are an important future area of research as provinces explore policies.

\section{Conclusion}

The results of our study illuminate the current pressure facing Ontarians because of rising drugs costs. With a larger number of expensive drugs currently under development, continued pressure on private insurers to control costs, and labour force trends, we anticipate that spending and use of the catastrophic drug program will continue to grow. Increased use of catastrophic drug programs across Canada should be an important area for policy-makers to take into consideration as discussions of pharmacare continue to develop.

\section{References}

1. Private drug plans in Canada: high-cost drugs and beneficiaries, 2005 to 2015. Ottawa: Patented Medicine Prices Review Board; 2016.

2. Barnes S, Abban V, Weiss A. Low wages, no benefits: expanding access to bealth benefits for low income Ontarians. Toronto: Wellesley Institute; 2015.

3. Uguccioni J, Sharpe A, Murray A. Labour productivity and the distribution of real earnings in Canada, 1976 to 2014. Ottawa: Centre for the Study of Living Standards; 2016.

4. Law MR, Kratzer J, Dhalla IA. The increasing inefficiency of private health insurance in Canada. CMA7 2014;186:E470-4.

5. Lepage S. What are the current drug plan trends in Canada? Benefits Canada 2015 Apr. 15.

6. Phillips K. Catastrophic drug coverage in Canada. Ottawa: Library of Parliament; 2016.

7. 2015/16 Report card for the Ontario Drug Benefit Program. Toronto: Ministry of Health and Long-Term Care; 2016.

8. Morgan SG, Li W, Yau B, et al. Estimated effects of adding universal public coverage of an essential medicines list to existing public drug plans in Canada. CMA7 2017;189:E295-302.
9. Morgan SG, Law M, Daw JR, et al. Estimated cost of universal public coverage of prescription drugs in Canada. CMA7 2015;187:491-7.

10. Schweitzer CL. The time is right for a national pharmacare program for Canada. Univ Toronto Med 7 2017;94:50-3.

11. Mamdani M, Juurlink DN, Kopp A, et al. Gastrointestinal bleeding after the introduction of COX 2 inhibitors: ecological study. BM7 2004;328:1415-6.

12. Juurlink DN, Gomes T, Ko DT, et al. A population-based study of the drug interaction between proton pump inhibitors and clopidogrel. CMAF 2009;180:713-8

13. Khan S, Moore JE, Gomes T, et al. The Ontario Drug Policy Research Network: bridging the gap between research and drug policy. Health Policy 2014;117:392-8

14. Guidelines for the economic evaluation of health technologies: Canada. Ottawa: Canadian Agency for Drugs and Technologies in Health; 2017.

15. Charlson M, Szatrowski TP, Peterson J, et al. Validation of a combined comorbidity index. 7 Clin Epidemiol 1994;47:1245-51.

16. Law MR, Ystma A, Morgan SG. The short-term impact of Ontario's generic pricing reforms. PLoS One 2011;6:e23030.

17. Prescribed drug spending in Canada, 2016: a focus on public drug programs. Ottawa: Canadian Institute for Health Information; 2016.

18. Protecting Canadians from excessive drug prices: consulting on proposed amendments to the patented medicines regulations. Ottawa: Patented Medicine Prices Review Board; 2016.

19. Canadian income survey, 2014. Ottawa: Statistics Canada; 2016.

20. Should developed countries, including Canada, provide universal access to essential medications through a national, publicly funded and administered insurance plan? Can 7 Hosp Pharm 2016;69:167-70.

21. Sullivan M. Change to make Trillium first payer could have major impact on private plans. Benefits Canada 2017 Jan. 5.

22. Morgan SG, Friesen MK, Thomson PA, et al. Use of product listing agreements by Canadian provincial drug benefit plans. Healthc Policy 2013;8:45-55.

23. Ontario Public Drug Programs. Toronto: Ontario Ministry of Health and Long-Term Care; 2017.

Affiliations: Li Ka Shing Knowledge Institute (Tadrous, Gomes), St. Michael's Hospital; Institute for Clinical Evaluative Sciences (Tadrous, Greaves, Martins, Mamdani, Juurlink, Gomes); Leslie Dan Faculty of Pharmacy (Tadrous, Mamdani, Gomes), University of Toronto; Institute of Health Policy, Management and Evaluation (Mamdani, Juurlink, Gomes), University of Toronto; Li Ka Shing Centre for Healthcare Analytics Research and Training (Mamdani), St. Michael's Hospital; Sunnybrook Research Institute (Juurlink), Toronto, Ont.

Contributors: All authors were involved in the design of the study, the interpretation of the results, the conceptualization of the recommendations and the writing and revision of the article. Mina Tadrous, Simon Greaves and Tara Gomes were involved in the implementation of the study. All authors gave approval of the final version for publication and agreed to be accountable for all aspects of the work.

Funding: This study was funded by a grant from the Ontario Ministry of Health and Long-Term Care (MOHLTC) Health System Research Fund and supported by the Institute for Clinical Evaluative Sciences (ICES), a non-profit research institute sponsored by the Ontario MOHLTC.

Acknowledgments: The authors thank Brogan Inc., Ottawa, for use of their Drug Product and Therapeutic Class Database. The authors would like to thank Anne MacDonald and Helen Patten, members of the Ontario Drug Policy Research Network Citizens' Panel, for their important input and insight throughout this project.

Supplemental information: For reviewer comments and the original submission of this manuscript, please see www.cmajopen.ca/content/6/1/ E132/suppl/DC1.

Disclaimer: The opinions, results and conclusions reported in this article are those of the authors and are independent from the funding sources. No endorsement by ICES or the Ontario MOHLTC is intended or should be inferred. Parts of this material are based on data and information compiled and provided by the Canadian Institute for Health Information (CIHI). However, the analyses, conclusions, opinions and statements expressed herein are those of the authors, and not necessarily those of CIHI. Muhammad Mamdani is a member of CMA7 Open's Editorial Advisory Board and was not involved in the editorial decision-making process for this article. 